\title{
Cytotoxic effects and radiosensitizing potential of Artemisia kopetdaghensis extract in human cervical cancel HeLa cells
}

Azar Fanipakdel ${ }^{1}$, Azar Hosseini², Sajedeh Tavakoli Afshar ${ }^{3}$, Mahnaz Nourbakhsh $^{4}$, Seyed Hadi Mousavi ${ }^{2,5,6}$

${ }^{1}$ M.D., Associate Professor of Radiation Oncology, Cancer Research Center, Mashhad University of Medical Sciences, Mashhad, Iran

${ }^{2}$ Pharm.D., PhD., Assistant Professor, Pharmacological Research Center of Medicinal Plants, Mashhad University of Medical Sciences, Mashhad Iran

${ }^{3}$ M.Sc. in Biophysics, Department of Biochemistry and Biophysics, Faculty of Sciences, Mashhad Branch, Islamic Azad University, Mashhad, Iran

${ }^{4}$ Pharm.D., PhD., Pharmaceutical Biotechnology Specialist, Cancer Research Center, Mashhad University of Medical Sciences, Mashhad, Iran

${ }^{5}$ M.D., PhD. Associate Professor, Medical Toxicology Research Center, Mashhad University of Medical Sciences, Mashhad, Iran

${ }^{6}$ Department of Pharmacology and Pharmacological Research Center of Medicinal Plants, School of Medicine, Mashhad University of Medical Sciences, Mashhad, Iran

Type of article: Original

\begin{abstract}
Background: Cervical cancer is one of the most common causes of cancer death in women worldwide; Radiotherapy has a major role in cervical cancer treatment. Anti-cancer effects of other species of Artemisia have been shown in some human cancer cells.

Objective: To determine the cytotoxic and radiosensitizing effects of Artemisia kopetdaghensis extract on cervical cancer HeLa cells.

Methods: Different concentrations of Artemisia kopetdaghensis extract (ART) $(25-250 \mu \mathrm{g} / \mathrm{ml})$ were examined on HeLa cell line. Cell cytotoxicity of the extract and combination of extract plus 2Gy radiation was evaluated after 24, 48 and 72 hours via MTT assay. ART induced apoptosis was estimated with flow cytometry after $24 \mathrm{~h}$. Oneway analysis of variance (ANOVA) and then Bonferroni post hoc test were applied for statistical analysis. Prism (v.6) was used for all statistical analyses.

Results: Artemisia kopetdaghensis decreased HeLa cells viability according to its concentration and timing of treatment. Comparing with the control group, a sub-G1 peak in the flow cytometry histogram of $A$. kopetdaghensis treated cells was shown, demonstrating that apoptosis was involved in A. kopetdaghensis cytotoxicity. Also, A. kopetdaghensis extract combined with irradiation, induced an additive cytotoxic effect on HeLa cells.

Conclusion: Artemisia kopetdaghensis extract might be considered as a radiosensitizer in cervical cancer treatment potentially, and can be a good candidate for future studies.

Keywords: HeLa cells, Artemisia kopetdaghensis, Cytotoxicity, Radiotherapy
\end{abstract}

Abbreviations / Acronyms:

ART: Artemisia Kopetdaghensis Extract, DMEM: Dulbecco's Modified Eagle's Medium, FBS: Fetal Bovine Serum, FIGO: International Federation of Gynecology and Obstetrics, PBS: Phosphate-Buffered Saline

\section{Corresponding author:}

Associate Professor Dr. Seyed Hadi Mousavi, Mashhad University of Medical Sciences, Mashhad, Iran.

Tel: +985138002258, Email: Mousavih@mums.ac.ir

Received: March 07, 2017, Accepted: May 14, 2018, Published: September 2019

iThenticate screening: November 09, 2017, English editing: May 15, 2018, Quality control: June 26, 2019

This article has been reviewed / commented by five experts

Funding / research project approval: 961670

(C) 2019 The Authors. This is an open access article under the terms of the Creative Commons Attribution-NonCommercialNoDerivs License, which permits use and distribution in any medium, provided the original work is properly cited, the use is non-commercial and no modifications or adaptations are made. 


\section{Introduction}

The combination of radiotherapy and chemotherapy has led to clinical success in the treatment of some cancers, and attempts to find optimum combinations of radiation with conventional chemotherapies, as well as new ones, continue. The ideal medications have radiosensitization effect to improve radiation response of tumor cells as well as radioprotection effect to prevent the toxicity of normal cells. Current work is an attempt in this field to find new nontoxic and preferably natural radiosensitizer agents to help us in cancer treatment (1). Cervical cancer is the secondary cause of cancer death in women and various treatment methods are used for its treatment (2). Based on the International Federation of Gynecology and Obstetrics (FIGO) division, cervical cancer has four clinical stages: stages I and II, which are early stages, stage III is locally advanced, and stage IV is the metastatic stage (3). Cervical cancer could be controlled by surgery and /or radiotherapy, or chemoradiotherapy (4). According to FIGO, concurrent chemoradiation is the first treatment line of locally advanced cervical cancer. In radiotherapy, because of normal tissue injury, the total dose of irradiation is limited. So, any combination therapy that can increase the radiotherapy efficiency without dose increment would be precious (5). Cisplatin is a well-known radiosensitizer that can be used for this cancer (6). Some other drugs that have been used for this purpose in clinical or nonclinical trials are carboplatin, paclitaxel, nedaplatin, gemcitabine, and camptothecins (7). Recently, natural components have been exploited for cancer treatment (8). Antibiotics such as bleomycin, mitomycin C, or plant derivatives such as bisindole alkaloids and taxanes are among these medicines (9). Active compounds were obtained from cruciferous vegetables such as broccoli, cabbage, cauliflower, and Brussels sprouts, which have shown radiosensitizing effect on head and neck carcinoma cell line (10). Also, pretreatment with sesamol enhances the irradiation efficacy in HeLa cells (11). Artemisia species are popular and traditional herbal medicines for the treatment of a variety of diseases and there have been a number of studies on their biological activities (12). Recent studies have shown the anticancer effect of some species of Artemisia, such as A. ciniformis (12) and A. absinthium (13). Another study has reported the cytotoxic effect of $A$. indica in four cancer cell lines, namely A-549, Caco-2, THP-1, and HEP-2 (14). Anti- proliferative activity of $A$. capillaris and A. herba-alba has been seen in human oral cancer and acute lymphoblastic leukemia cell lines, respectively $(15,16)$. Artemisia kopetdaghensis is an aromatic member of the Asteraceae family. It is used in Iranian traditional medicine as an anti-inflammatory, antimicrobial, antifungal, and sedative. In this research, we investigated the anticancer effects of $A$. kopetdaghensis. We chose this plant because it is native to our province, and its extract was available. Moreover, the research team decided to study cervical cancer, because it is usually an advanced cancer, and surgery is not possible; therefore, its main treatment would usually be chemoradiotherapy. For this purpose, we evaluated the cytotoxic activity of $A$. kopetdaghensis extract and its radiosensitization effect in HeLa cells for the first time.

\section{Material and Methods}

\subsection{Cell line/chemical agents}

HeLa cell line was prepared by the Pasteur Institute. Sodium citrate, propidium iodides (PI), 4, 5-Dimethylthiazol-2yl, 2, 5-diphenyl tetrazolium (MTT), Triton X-100, and Dulbecco's Phosphate-buffered saline (PBS) were obtained from Sigma (St Louis, MO, USA). Fetal bovine serum (FBS), penicillin streptomycin and Glucose-high Dulbecco's modified Eagle's medium (DMEM) were purchased from Gibco (Grand Island, NY). Dimethyl sulfoxide (DMSO) was obtained from Merck.

\subsection{Irradiation}

Cells were irradiated with dose rate of 120 centigray (cGy)/min from a $60 \mathrm{Co} \gamma$-irradiation source (Theratone780, Canada). Source to surface distance (SSD) was $80 \mathrm{~cm}$. Radiation dose was 2 Gray (Gy) radiated with $9 \times 5$ field size.

\subsection{Preparation of extract}

A. kopetdaghensis shrubs were collected from Gonabad (Northeast Iran) and identified by the herbarium of Ferdowsi University of Mashhad, Iran (voucher specimen number: 35205). The herb was dried and the extraction carried out for $48 \mathrm{~h}$ with $70 \%$ ethanol using a Soxhlet apparatus. After drying the extract in water bath, it was dissolved in DMSO and was stored at $-20{ }^{\circ} \mathrm{c}$.

\subsection{Cell culture}

The cells were cultured in DMEM which contained FBS $(10 \%)$ and penicillin/streptomycin $(100 \mathrm{unit} / \mathrm{mL})$ then kept in an incubator $\left(\mathrm{O}_{2}: 90 \%, \mathrm{CO}_{2}: 95 \%\right.$, temperature: $\left.37^{\circ} \mathrm{C}\right)$.

\subsection{Determination of A. kopetdaghensis extract cytotoxicity by MTT assay}

The cells were exposed to various doses of extract $(25-250 \mu \mathrm{g} / \mathrm{ml})$ for 24,48 and $72 \mathrm{~h}$. After the passing of these times, for assessing cell metabolic activity, MTT solution $(5 \mathrm{mg} / \mathrm{mL})$ was added to each well. The plates were 
incubated for $4 \mathrm{~h}$ at $37^{\circ} \mathrm{C}$, then the reaction mixture was eliminated and the formazan crystals were dissolved by adding $100 \mu \mathrm{l}$ DMSO to each well. The optical density was read using an ELISA micro plate reader at $570 \mathrm{~nm}$ and $630 \mathrm{~nm}$.

\subsection{Determination of Combined effects of A. kopetdaghensis extract and irradiation by cytotoxicity assay}

For evaluation of extract and irradiation, the cells were treated with extract for 24,48 and $72 \mathrm{~h}$. After these times, cells were washed with PBS. Cells were exposed with irradiation (60 Co unit at a dose of 2 Gy $\gamma$-rays) (17). After irradiation, PBS was replaced with fresh DEMEM medium. The cells were incubated for $66 \mathrm{~h}$ and then MTT assay was done (18).

\subsection{Detection of apoptosis induced by A. kopetdaghensis extract via flow cytometry}

The PI test was used for detection of apoptotic cells. In this assay, cells were treated with extract at different doses. Then, cells were harvested and incubated with hypotonic buffer $(50 \mu \mathrm{g} / \mathrm{ml}$ PI in $0.1 \%$ sodium citrate with $0.1 \%$ Triton X-100) at $4{ }^{\circ} \mathrm{C}$. After overnight incubation, the level of apoptosis was read by flow cytometer (Becton Dickinson).

\subsection{Statistical analysis}

All data in the different experimental groups were expressed as the mean \pm SEM. At least three independent experiments were done for each assay. For multi-group comparisons, one-way analysis of variance (ANOVA) and then Bonferroni post hoc tests were performed; $\mathrm{p}<0.05$ was considered as statistically significant. Graphpad Prism (v.6) was used for all statistical analyses.

\section{Results}

\subsection{Cytotoxic effect of A. kopetdaghensis extract on HeLa cells}

To evaluate the toxic effects of $A$. kopetdaghensis, HeLa cells were incubated with different concentrations (25-250 $\mu \mathrm{g} / \mathrm{ml}$ ) of the extract, and the cell viability was determined 24,48 and $72 \mathrm{~h}$ after treatment. As demonstrated in Table 1 and Figure 1, A. kopetdaghensis extract reduced cell viability in HeLa cell line depending on concentration and timing. High doses of extract $(100-250 \mu \mathrm{g} / \mathrm{mL})$ could reduce the cell viability significantly $(\mathrm{p}<0.001)$ at all times. This is while lower doses of extract $(25-50 \mu \mathrm{g} / \mathrm{mL})$ could reduce the cell viability after $48 \mathrm{~h}(\mathrm{p}<0.05$ and $\mathrm{p}<0.01$ respectively) and after $72 \mathrm{~h}(\mathrm{p}<0.001)$ significantly.

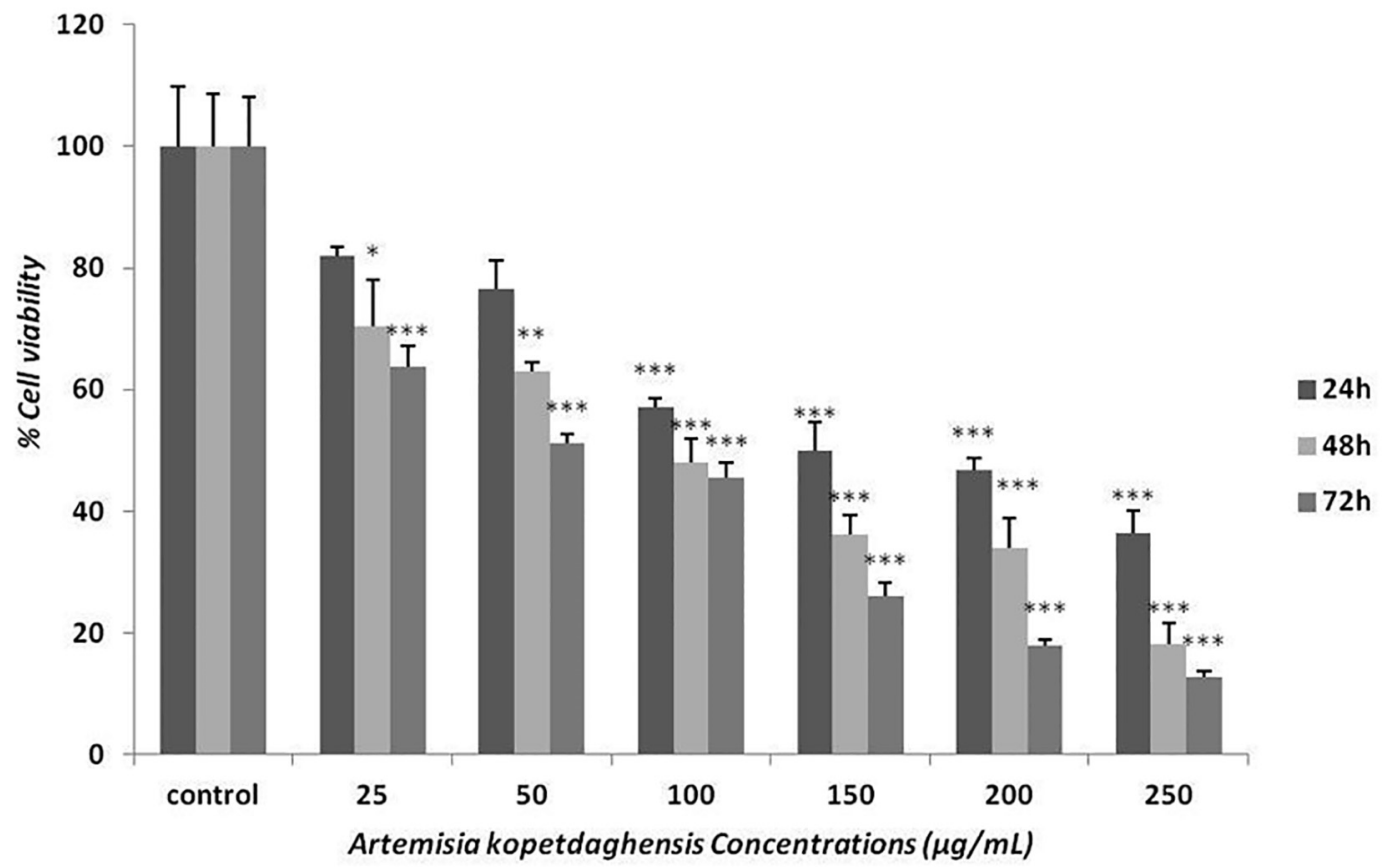

Figure 1. The cytotoxic effect of $A$. kopetdaghensis on HeLa cells. HeLa cells were treated with various concentrations of $A$. kopetdaghensis for $24 \mathrm{~h}, 48 \mathrm{~h}$, and $72 \mathrm{~h}$. Viability was quantitated by the MTT assay. The data are expressed as mean $\pm \operatorname{SEM}(\mathrm{n}=3) .{ }^{*} \mathrm{p}<0.05, * * \mathrm{p}<0.01$, and $* * * \mathrm{p}<0.001$ 
Table 1. The cytotoxic effect of A. kopetdaghensis extract on HeLa cells.

\begin{tabular}{|l|l|l|l|l|l|l|}
\hline \multirow{2}{*}{ Extract concentrations } & \multicolumn{9}{l}{ \% Cell Viability } \\
\cline { 2 - 7 } & \multicolumn{2}{|l|}{ After 24 h } & \multicolumn{2}{l|}{ After 48 h } & \multicolumn{2}{l|}{ After 72 h } \\
\cline { 2 - 7 } & Mean & SEM & Mean & SEM & Mean & SEM \\
\hline Control & 100 & 9.917 & 100 & 8.482 & 100 & 8.029 \\
\hline $25(\mu \mathrm{g} / \mathrm{mL})$ & 81.87 & 1.538 & 70.39 & 7.754 & 63.68 & 3.526 \\
\hline $50(\mu \mathrm{g} / \mathrm{mL})$ & 76.59 & 4.613 & 62.97 & 1.486 & 51.11 & 1.613 \\
\hline $100(\mu \mathrm{g} / \mathrm{mL})$ & 57.06 & 1.561 & 47.95 & 4.094 & 45.43 & 2.482 \\
\hline $150(\mu \mathrm{g} / \mathrm{mL})$ & 49.9 & 4.625 & 36.19 & 3.224 & 25.98 & 2.39 \\
\hline $250(\mu \mathrm{g} / \mathrm{mL})$ & 36.35 & 3.631 & 18.07 & 3.491 & 12.66 & 0.9613 \\
\hline
\end{tabular}

\subsection{Combined effects of A. kopetdaghensis extract and irradiation on HeLa cells}

A single irradiation dose of 2 Gy diminished cell viability in HeLa cell line about $43 \%$ (Cell viability $=57.3 \pm 2.2 \%$ of control cells, $\mathrm{p}<0.001$ ); Data are shown in Table 1 . To determine whether plant extract can increase radiotherapy effect, we treated the cells with extract for 24,48 and $72 \mathrm{~h}$ before irradiation treatment. Irradiation plus plant extract increased HeLa cells cytotoxic response modestly (Figure 2, Table 2). In each concentration, cell viability reduced with increasing of incubation time. For example, while the concentration of $25 \mu \mathrm{g} / \mathrm{mL}$ at $24 \mathrm{~h}$ could not reduce cell viability compared to $2 \mathrm{~Gy}$ irradiation control group, it reduced cell viability $14.4 \%$ more than $2 \mathrm{GY}$ control group at $72 \mathrm{~h}$. Furthermore, in each incubation time, as we expected, cell viability reduced by increasing the dose of the extract. However, comparison of the cytotoxicity of the extract alone (Figure 1), and 2 Gy radiotherapy (2 Gy control group of Figure 2), to the cytotoxicity of combination therapy (Figure 2), reveals these cell viability reductions are less than levels that $A$. kopetdaghensis extract and $2 \mathrm{~Gy}$ radiation have any synergistic effect.

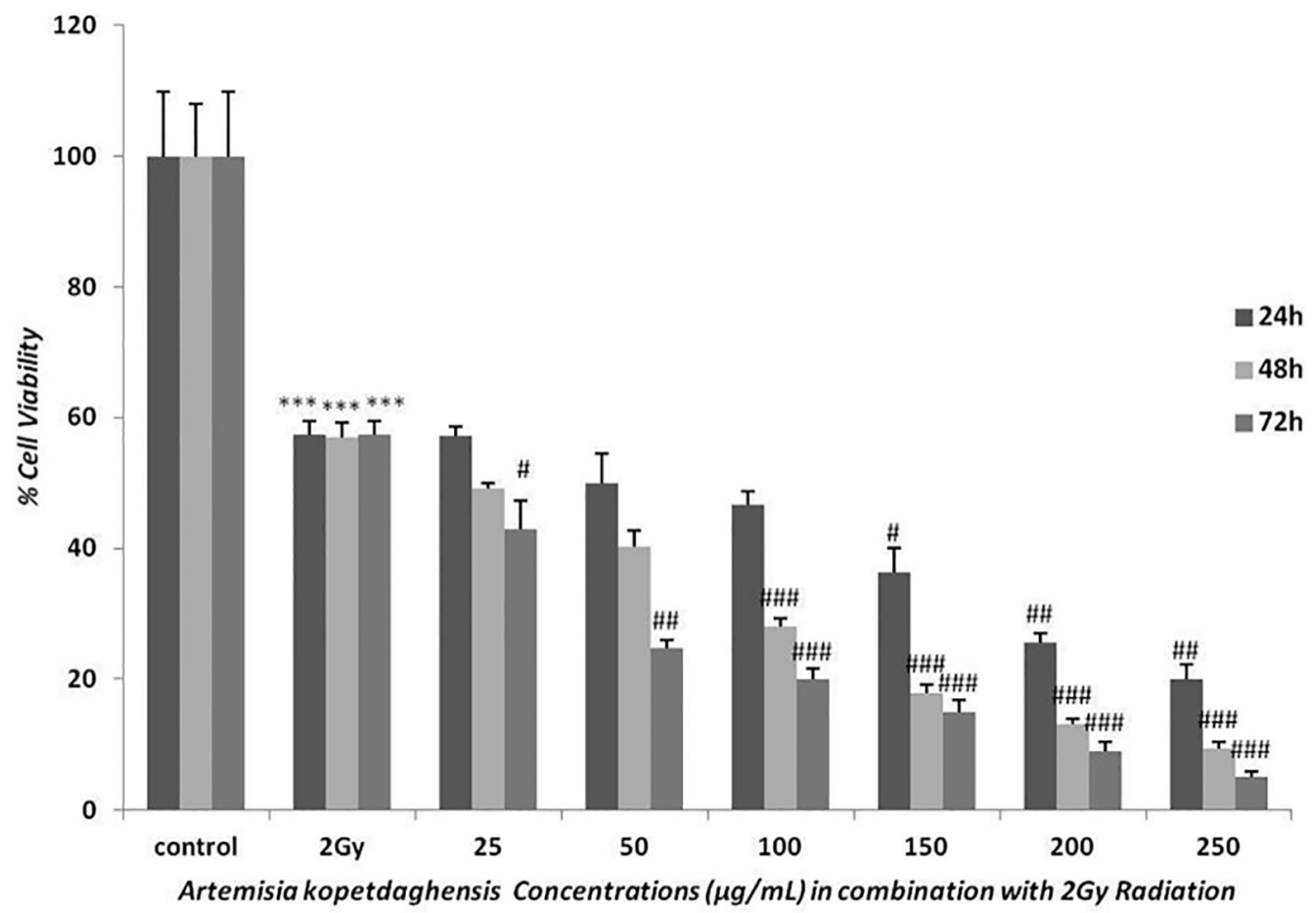

Figure 2. Evaluation of cytotoxic effect of irradiation associated with extract in HeLa cell line. HeLa cells were pretreated with various concentrations of $A$. kopetdaghensis for $24 \mathrm{~h}, 48 \mathrm{~h}$, and $72 \mathrm{~h}$. Then, all the cells

(Except control groups) irradiated with $2 \mathrm{~Gy} \gamma$ ray. Viability was quantitated by the MTT assay after $66 \mathrm{~h}$.

The data are expressed as mean $\pm \operatorname{SEM}(\mathrm{n}=3)$. $* * * \mathrm{p}<0.001$ compared with control ( $\mathrm{p}$-values of all combination therapy groups are less than 0.001 , data not shown). $\# \mathrm{p}<0.05$, \#\# $\mathrm{p}<0.01$ and $\# \# \# \mathrm{p}<0.001$ compared with just 2 Gy irradiated control groups. 
Table 2. Cell viability in different treated Hela cells with various concentrations of Artemisia kopetdaghensis extract (ART) and 2 Gy radiation.

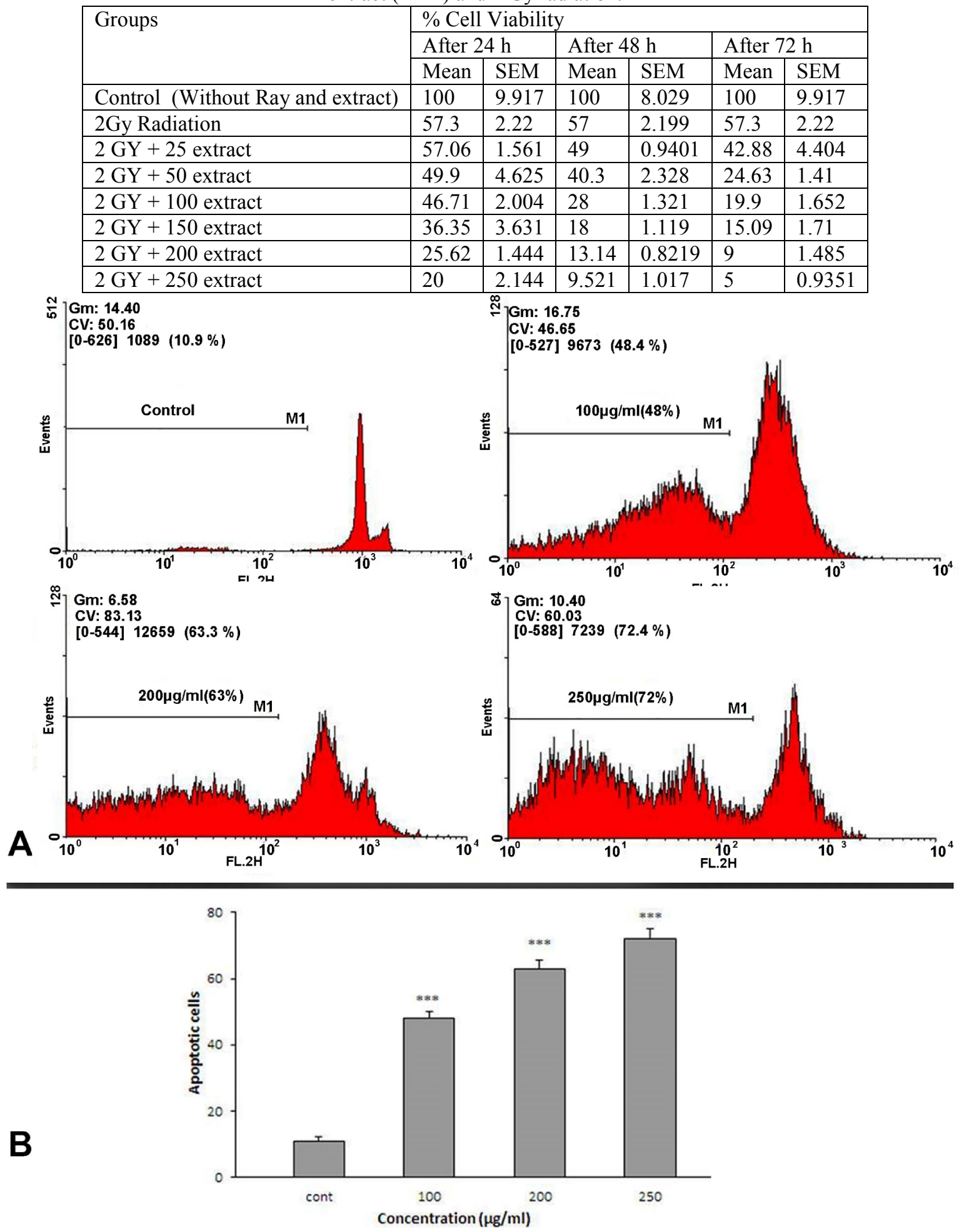

Figure 3. The role of apoptosis in A. kopetdaghensis induced toxicity in HeLa cells. Apoptosis assayed by using PI staining and flow cytometry. HeLa Cells were treated with different concentrations of the extract (100, 200 and 250 $\mu \mathrm{g} / \mathrm{mL}$ ) for $24 \mathrm{~h}$. A sub-G1 peak, as an indicator of apoptotic cells, was induced in the A. kopetdaghensis -treated cells but not in the control cells (A). The percentages of apoptotic cells in the HeLa cells treated with different concentrations of $A$. kopetdaghensis have been shown. ${ }^{* *} \mathrm{p}<0.001$ versus control group (B). 


\subsection{Apoptotic activity of A. kopetdaghensis against HeLa cell line}

To clarify the role of apoptosis in the extract cytotoxicity, HeLa cells were incubated with different concentrations $(100-250 \mu \mathrm{g} / \mathrm{ml})$. Cell apoptosis was assessed $24 \mathrm{~h}$ after treatment. As shown in Figure 3, treatment with extract significantly increased cell apoptosis in HeLa cell line as a concentration-dependent manner $(\mathrm{p}<0.001)$.

\section{Discussion}

Radiotherapy is an effective method for inducing tumor cell death. (5). Tumor cells grow very rapidly; they overgrow their vascular blood supply, resulting in centrally necrotic and hypoxic regions, rendering radiation ineffective in these areas (19). To overcome this problem, higher doses of radiation must be delivered to control the tumor. But, since the normal tissues surrounding the tumor are oxygenated and prone to radiation damage, this is not actually an easy procedure by conventional methods. (20). Success of radiotherapy, therefore, depends on increasing the sensitivity of the cancer cells to radiation (21). Ionizing radiation has been shown to develop reactive oxygen species (ROS) in cells (22). The exposure to factors that increase oxidative stress-induced injury may sensitize cells to ionizing radiation. Luo et al. examined the use of a combined drug Artesunate (ART), (An Artemisinin derivative) with radiation in cervical cancer cells. They found that the concomitant administration of ART and irradiation enhanced apoptosis in HeLa cells. They showed this radiosensitization was associated with cell cycle progression changes by the G2 checkpoint canceling (23). Britten et al. showed that treatment with a combination of radiotherapy and cisplatin increased the rates of death in cervical cancer cell line (24) Recent studies by Rose et al. demonstrated that regimens of radiotherapy and concurrent chemotherapy (cisplatin) progressed the rates of survival and progression-free survival in locally advanced cervical cancer (25). Plumbagin pretreatment also enhances irradiation effects by HeLa and SiHa cell proliferation inhibiting in vitro (19). Ursolic acid and oleanolic acid inhibit colon carcinoma cell line HCT15 proliferation (26). (-)-Epigallocatechin-3- gallate promotes growth inhibition of T24 bladder cancer cells by inducing apoptosis via modulation of the PI3K/ Akt pathway (27). Also, the effects of radiation on HeLa cells can be enhanced by pretreatment with sesamol (11). Since no information was available on the effects of $A$. kopetdaghensis combined with radiotherapy, this study determined the effects of A. kopetdaghensis, combined with radiation on HeLa cell line. At the first step, we determined the cytotoxicity and anticancer effects of A. kopetdaghensis on HeLa cells. Our data showed that A. kopetdaghensis decreased cell surveillance depending on the dose and timing. Then, in the combination therapy step, we observed that this extract particularly in a longer period of pretreatments, increased the sensitization of HeLa cells to radiation. Some of the biological components of Artemisia genus are coumarins, flavonoids, phenylpropanoids, glycosides, sterols and terpenoids, (28). Polyphenols, a group of compounds with high antioxidant activity, are rich in ethanolic and aqueous extracts. Different studies have shown that polyphenols can protect cells from radiation damage (29).

Flavonoids are a group of polyphenol substances which are found in most of the plants. These substances have several bioactivities, containing antioxidant (30) and radioprotective effects (29). In the presence of transition metals, they can shift to pro-oxidant activity. Flavonoids promote cellular toxicity via pro-oxidant activity and lead to DNA damage. The intracellular copper level is higher in cancer cells, however, flavonoid - $\mathrm{Cu}(\mathrm{II})$ complex has more cytotoxic effects in cancer cells than in normal cells (31). Sahu and Washington (1992) (32) showed the pro-oxidant effect of curcumin on irradiated cells under certain circumstances, thus stimulating radiation damage. However, increasing sensitization of HeLa cells to radiation is related to its flavonoids. Previous reports showed that phenolic phytochemicals enhanced radiation effects (33). In recent years, some studies indicated that natural products could induce apoptosis in cervical cancer cells (10). As apoptotic pathways are deregulated in cancer, apoptosis inducing in HeLa cell line shows antineoplastic therapy (34). In our study, flow cytometric analysis showed hydro-alcoholic extract of $A$. kopetdaghensis induced apoptosis in cervical cancer cells. This is concordant with our previous study in which we demonstrated that A. kopetdaghensis increased cell toxicity, probably via inducing apoptosis, in ACHN cell line (35). Recent studies have shown cytotoxic effect of Artemisia is due to the increased amount of Bax protein and DNA fragmentation that finally induces apoptotic pathway (12). In the case of combination therapy of the extract and radiation, no radiosensitizer effect can be recognizable at high doses of the extract or radiation because of high cell toxicity. So, suitable doses of extract $(25-250 \mu \mathrm{g} / \mathrm{ml})$ and radiation (2 Gy) were used in this study. As expected, the differences between cytotoxicity of extract and combination therapy, reduced at high concentrations. Our results demonstrated A. kopetdaghensis extract increased cell death in combination with radiotherapy (except in the concentrations of $25 \mu \mathrm{g} / \mathrm{mL}$ after $24 \mathrm{~h}$ ). So, the best situations of extract for using as radiosentisizers may be the low concentrations $(25-50 \mu \mathrm{g} / \mathrm{mL})$ at 48 and $72 \mathrm{~h}$ incubation times. Low concentrations with less toxicity could sensitize the cancer cells and reduce cell viability up to $32.7 \%$ (50 $\mu \mathrm{g} / \mathrm{mL}$ at $72 \mathrm{~h}$ ) compared with 2 Gray control group. 


\section{Conclusions}

Pre-treatment with Artemisia kopetdaghensis extract before radiation caused an additive cytotoxic effect in HeLa cells. Based on the dedication results, we propose that this plant might be a good source of components for cervical cancer treatment, especially when the cells are resistant to radiotherapy alone. So, Artemisia kopetdaghensis can be a good radiosensitizer candidate for more studies.

\section{Acknowledgments:}

This work was derived from a Master of Science thesis by Mrs. Sajedeh Tavakoli Afshar, and supported by the Pharmacological Research Center of Medicinal Plants, School of Medicine, Mashhad University of Medical Sciences, Mashhad, Iran (grant number: 961670).

\section{Conflict of Interest:}

There is no conflict of interest to be declared.

Authors' contributions:

All authors contributed to this project and article equally. All authors read and approved the final manuscript.

\section{References:}

1) Spalding AC, Lawrence TS. New and emerging radiosensitizers and radioprotectors. Cancer investigation. 2006 Jun-Jul; 24(4):444-56. doi: 10.1080/07357900600705706. PMID: 16777698.

2) Petignat P, Roy M. Diagnosis and management of cervical cancer. Bmj. 200 7Oct 13; 335(7623):765-8. doi: 10.1136/bmj.39337.615197.80. PMID: 17932207.

3) Benedet JL, Bender H, Jones H, 3rd, Ngan HY, Pecorelli S. FIGO staging classifications and clinical practice guidelines in the management of gynecologic cancers. FIGO Committee on Gynecologic Oncology. International journal of gynaecology and obstetrics: the official organ of the International Federation of Gynaecology and Obstetrics. 2000 Aug; 70(2):209-62. doi: 10.1016/S0020-7292(00)90001-8, PMID: 11041682.

4) Kimura T, Miyatake T, Ueda Y, Ohta Y, Enomoto T, Kimura T, et al. Cervical non-squamous carcinoma: an effective combination chemotherapy of taxane, anthracycline and platinum for advanced or recurrent cases. European journal of obstetrics, gynecology, and reproductive biology. 2012 Oct; 164(2):200-4. doi: 10/1016.j.ejogrb.2012.06.008. PMID: 22770633.

5) Nair S, Nair RR, Srinivas P, Srinivas G, Pillai MR. Radiosensitizing effects of plumbagin in cervical cancer cells is through modulation of apoptotic pathway. Molecular carcinogenesis. 2008 Jan; 47(1):22-33. doi: 10.1002/mc.20359. PMID: 17562542.

6) Pearcey R, Brundage M, Drouin P, Jeffrey J, Johnston D, Lukka H, et al. Phase III trial comparing radical radiotherapy with and without cisplatin chemotherapy in patients with advanced squamous cell cancer of the cervix. Journal of Clinical Oncology. 2002; 20(4):966-72. doi: 10.1200/JCO.2002.20.4.966, PMid: 11844818

7) Candelaria M, Garcia-Arias A, Cetina L, Duenas-Gonzalez A. Radiosensitizers in cervical cancer. Cisplatin and beyond. Radiation oncology. 2006 May 08; 1:15. doi: 10.1186/1748-717X-1-15. PMID: 1672254.9

8) Ji HF, Li XJ, Zhang HY. Natural products and drug discovery. Can thousands of years of ancient medical knowledge lead us to new and powerful drug combinations in the fight against cancer and dementia? EMBO reports. 2009 Mar; 10(3):194-200. doi: 10.10/38embor.2009.12. PMID: 19229284.

9) Frank JH, Kanamitsu K. Paederus, sensu lato (Coleoptera: Staphylinidae): natural history and medical importance. Journal of medical entomology. 1987 Mar; 24(2):155-91. doi: 10.1093/jmedent/24.2.155, PMID: 3295241.

10) Kotowski U, Heiduschka G, Brunner M, Czembirek C, Eder-Czembirek C, Schmidt R, et al. Radiosensitization of head and neck cancer cells by the phytochemical agent sulforaphane. Strahlentherapie und Onkologie : Organ der Deutschen Rontgengesellschaft [et al]. 2011 Sep; 187(9):575-80. doi: 10.1007/s00066-011- 2218-6. PMID: 21858418.

11) Shanmugham M, Prasad NR. Radiosensitizing effect of sesamol on human cervical carcinoma cells. International Journal of Nutrition, Pharmacology, Neurological Diseases. 2012; 2(3):210. doi: 10.4103/2231-0738.99472

12) Tayarani-Najaran Z ,Hajian Z, Mojarrab M, Emami SA. Cytotoxic and apoptotic effects of extracts of Artemisia ciniformis Krasch. and Popov ex Poljakov on K562 and HL-60 cell lines. Asian Pacific journal 
of cancer prevention: APJCP. 2014; 15(17):7055-9. doi: 10.7314/APJCP.2014.15.17.7055, PMID: 25227790.

13) Taherkhani M. In vitro cytotoxic activity of the essential oil extracted from Artemisia absinthium. Iranian Journal of Toxicology. 2014; 8(26):1152-6.

14) Rashid S, Rather MA, Shah WA, Bhat BA. Chemical composition, antimicrobial, cytotoxic and antioxidant activities of the essential oil of Artemisia indica Willd. Food chemistry. 2013 May 01; 138(1):693-700. doi: 10.1016/j.foodchem.2012.10.102. PMID: 23265542.

15) Cha JD, Moon SE, Kim HY, Cha IH, Lee KY. Essential oil of Artemisia capillaris induces apoptosis in KB cells via mitochondrial stress and caspase activation mediated by MAPK-stimulated signaling pathway. Journal of food science. 2009 Nov-Dec; 74(9):T75-81. doi: 10.1111/j.1750-3841.2009.01355.x. PMID: 20492133.

16) Tilaoui M, Mouse HA, Jaafari A, Aboufatima R, Chait A, Zyad A. Chemical composition and antiproliferative activity of essential oil from aerial parts of a medicinal herb Artemisia herba-alba. Revista Brasileira de Farmacognosia. 2011; 21(4):781-5. doi: 10.1590/S0102-695X2011005000114

17) Magne N, Fischel JL, Dubreuil A, Formento P, Marcie S, Lagrange JL, et al. Sequence-dependent effects of ZD1839 ('Iressa') in combination with cytotoxic treatment in human head and neck cancer. British journal of cancer. 2002 Mar 04; 86(5):819-27. doi: 10.1038/sj.bjc.6600103. PMID: 11875748, PMCid: PMC2375300

18) Torres MA, Raju U, Molkentine D, Riesterer O, Milas L, Ang KK. AC480, formerly BMS-599626, a pan Her inhibitor, enhances radiosensitivity and radioresponse of head and neck squamous cell carcinoma cells in vitro and in vivo. Investigational new drugs. 20 11Aug; 29(4):554-61. doi: 10.1007/s10637-010-9389-3. PMID: 20119866.

19) Vaupel P. Tumor microenvironmental physiology and its implications for radiation oncology. Seminars in radiation oncology. 2004 Jul; 14(3):198-206. doi: 10.1016/j.semradonc.2004.04.008 .PMID:15254862.

20) Nair CK, Parida DK, Nomura T. Radioprotectors in radiotherapy. Journal of radiation research. 2001 Mar; 42(1):21-37. doi: 10.1269/jrr.42.21, PMID: 11393887.

21) Wardman P. Chemical radiosensitizers for use in radiotherapy. Clinical Oncology. 2007; 19(6):397-417. doi: 10.1016/j.clon.2007.03.010, PMid: 17478086

22) Dal-Pizzol F, Ritter C, Klamt F, Andrades M, da Frota ML, Jr., Diel C, et al. Modulation of oxidative stress in response to gamma-radiation in human glioma cell lines. Journal of neuro-oncology. 2003 Jan; 61(2):8994. doi: 10.1023/A:1022168805198, PMID: 12622446.

23) Luo J, Zhu W, Tang Y, Cao H, Zhou Y, Ji R, et al. Artemisinin derivative artesunate induces radiosensitivity in cervical cancer cells in vitro and in vivo. Radiation oncology. 2014 Mar 25; 9:84. doi: 10.1186/1748-717X-9-84. PMID: 24666614, PMCid: PMC3987175

24) Britten RA, Evans AJ, Allalunis-Turner MJ, Pearcey RG. Effect of cisplatin on the clinically relevant radiosensitivity of human cervical carcinoma cell lines. International journal of radiation oncology, biology, physics. 1996 Jan 15; 34(2):367-74. doi: 10.1016/0360-3016(95)02088-8, PMID: 8567337.

25) Rose PG, Bundy BN, Watkins EB, Thigpen JT, Deppe G, Maiman MA, et al. Concurrent cisplatin-based radiotherapy and chemotherapy for locally advanced cervical cancer. The New England journal of medicine. 1999 Apr 15; 340(15):1144-53. doi: 10.1056/NEJM199904153401502. PMID: 10202165.

26) Li J, Guo WJ, Yang QY. Effects of ursolic acid and oleanolic acid on human colon carcinoma cell line HCT15. World journal of gastroenterology. 2002 Jun; 8(3):493-5. doi: 10.3748/wjg.v8.i3.493, PMID: 12046077, PMCid: PMC4656428

27) Qin J, Xie LP, Zheng XY, Wang YB, Bai Y, Shen HF, et al. A component of green tea, (-)epigallocatechin-3-gallate, promotes apoptosis in T24 human bladder cancer cells via modulation of the PI3K/Akt pathway and Bcl-2 family proteins. Biochemical and biophysical research communications. 2007 Mar 23; 354(4):8 .52-7doi: 10.1016/j.bbrc.2007.01.003. PMID: 17266926.

28) Afshar FH, Delazar A, Janneh O, Nazemiyeh H, Pasdaran A, Nahar L, et al. Evaluation of antimalarial, free-radical-scavenging and insecticidal activities of Artemisia scoparia and A. Spicigera, Asteraceae. Revista Brasileira de Farmacognosia. 2011; 21(6):986-90. doi: 10.1590/S0102-695X2011005000144

29) Shimoi K, Masuda S, Furugori M, Esaki S, Kinae N. Radioprotective effect of antioxidative flavonoids in gamma-ray irradiated mice. Carcinogenesis. 1994 Nov; 15(11):2669-72. doi: 10.1093/carcin/15.11.2669, PMID: 7955124

30) Pietta P-G. Flavonoids as antioxidants. Journal of natural products. 2000; 63(7):1035-42. doi: $10.1021 /$ np9904509 
31) Hosseinimehr SJ. Flavonoids and genomic instability induced by ionizing radiation. Drug discovery today. 2010 Nov; 15(21-22):907-18. doi: 10.1016/j.drudis.201 .0.09.005. PMID: 20933097.

32) Sahu SC, Washington MC. Effect of ascorbic acid and curcumin on quercetin-induced nuclear DNA damage, lipid peroxidation and protein degradation. Cancer letters. 1992 Apr 30; 63(3):237-41. doi: 10.1016/0304-3835(92)90266-X, PMID: 1576592.

33) Chendil D, Ranga RS, Meigooni D, Sathishkumar S, Ahmed MM. Curcumin confers radiosensitizing effect in prostate cancer cell line PC-3. Oncogene. 2004 Feb 26; 23(8):1599-607. doi: 10.1038/sj.onc.1207284. PMID: 14985701.

34) Hanahan D, Weinberg RA. The hallmarks of cancer. Cell 2000 .Jan 07; 100(1):57-70. doi: 10.1016/S00928674(00)81683-9, PMID: 10647931.

35) Mousavi SH, Hosseini A, KajaviRad A, Bakhtiary E, Shahraki S, Havakhah S, et al. The evaluation and comparing of cytotoxic effects of Ferula gummosa gum, Scutellaria lindbergii, Kelussia odoratissima and Artemisia kopetdaghensis extracts on ACHN cell line. Iranian Journal of Pharmaceutical Research. 2017; 16(3):1104-12. 